\title{
Occurrence of the parasitoid Anastatus sp. in eggs of Leptoglossus zonatus under the maize in Brazil
}

\author{
Ocorrência do parasitóide Anastatus sp em ovos de Leptoglossus \\ zonatus em milho no Brasil
}

Carlos Henrique Marchiori ${ }^{1}$

- NOTE -

\section{ABSTRACT}

The objective of this study was to report, for the first time in Brazil, the occurrence of the parasitoid Anastatus sp. (Hymenoptera: Eupelmidae) in eggs of Leptoglossus zonatus (Hemiptera: Coreidae) on maize (Zea mays L.) in Itumbiara County, State of Goias, Brazil (18²5'S; $49^{\circ} 13^{\prime} \mathrm{W}$ ). Percent parasitism was $6.9 \%$.

Key words: Anastatus, Zea mays, Leptoglossus zonatus, crop pest, parasitoid.

RESUMO

O objetivo dessa nota é registrar a primeira ocorrência, no Brasil, do parasitóide Anastatus sp. (Hymenoptera: Eupelmidae) em ovos de Leptoglossus zonatus (Hemiptera: Coreidae) em cultivar de milho em Itumbiara, Estado de Goiás $\left(18^{\circ} 25^{\prime} \mathrm{S} ; 49^{\circ} 13^{\prime} \mathrm{W}\right)$. A porcentagem de parasitismo foi de $6,9 \%$

Palavras-chave: Anastatus, Zea mays, Leptoglossus zonatus, praga agrícola, parasitóide.

The family Eupelmidae presents its highest diversity in the Neotropical region and comprises three subfamilies: Calosotinae, Neanastatinae and Eupelminae. Many species of these subfamilies are distributed in tropical and subtropical regions around the world. The majority of the Calosotinae and
Neanastatinae attack larvae of Coleoptera borers while the Eupelminae parasitize a wide range of hosts, which include eggs of spiders and immature stages of Orthoptera, Blattaria, Mantodea, Hemiptera, Homoptera, Neuroptera, Coleoptera, Diptera, Lepidoptera and Hymenoptera. Many species are polyphagous, accepting a diversity of hosts of similar appearance that occupy a common ecological niche (GRISSEL \& SCHAUFF, 1990).

Species of Eupelmidae, especially those that attack eggs of insects, develop as idiobionts endoparasitoids. Several species have been used in biological control programs (GRISSELL \& SCHAUFF, 1990; PERIOTO \& TAVARES, 1999). Many species in the genus Anastatus are primary endoparasitoids of eggs on a wide range of insects, including Blattaria, Hemiptera, Homoptera, Lepidoptera, Mantodea, Neuroptera, Orthoptera, Heteroptera and Phasmida (HANSON \& GAULD, 1995).

Leptoglossus zonatus commonly known as maize bug also occur on sorghum, bean, soybean, tomato and citrus. It sucks grains and fruits causing wilting and decay, thus reducing yield. It is more important for maize, on which losses may reach $15 \%$. This hemipterous has

${ }^{1}$ Biólogo, Doutor, Professor Titular do Departamento de Ciências Naturais do Instituto Luterano de Ensino Superior de Itumbiara, ILES-ULBRA, Avenida Beira Rio, 1001, Bairro Nova Aurora, 75500-000, Itumbiara, Goiás. Fax (62) 3431-8239, pesquisa.itb@ulbra.br. Autor para correspondência. 
already been found in Mexico, Central and South America and occurs mainly from December to April (ZUCCHI et al., 1993).

The objective of this scientific study was to report, for the first time in Brazil, the occurrence of the parasitoid Anastatus sp. parasitizing eggs of $\boldsymbol{L}$. zonatus.

The experiment was carried out at the College of Agronomy Farm, located in Itumbiara County, State of Goias, Central Brazil (18 $25^{\prime} \mathrm{S}$; $\left.49^{\circ} 13^{\prime} \mathrm{W}\right)$. Samples were obtained in a $44 \mathrm{~m} \times 22 \mathrm{~m}$ maize (Zea mays L.) field plot, where 50 ears of maize (cultivar Dekalb 601) were randomly harvested, individualized in plastic bags and taken to the laboratory of the Instituto Luterano de Ensino Superior (Lutheran Institute of Superior Teaching) for Hemiptera eggs collection. The presence of eggs (egg masses oviposited on a straight line) was verified on each single ear of maize. In order to obtain parasitoids, each egg mass was placed near a small piece of maize leaf sheath inside a glass flask that was maintained in the laboratory, at room temperature, until emergence of parasitoids and/or nymphs of the insect pest.

Samplings were weekly performed from December 2001 to February 2002. Percent parasitism was computed by using the following formula: $\mathrm{P}=$ (parasitized eggs/total eggs) $\times 100$.

Seventy-two eggs of $L$. zonatus were collected in January 15 of 2002, from which five parasitoids of the genus Anastatus (Hymenoptera: Eupelmidae) emerged. The prevalence of parasitism observed was $6.9 \%$. The use of chemicals in controlling crop pests may result in increased production costs as well as in damages to the environment and to human health. TORRES et al. (1996) indicated the occurrence of Anastatus spp. in eggs of Podisus nigrispinus (DALLAS) (Heteroptera: Pentatomidae) collected in plantations of Eucalyptus sp. in the State of Minas Gerais, Brazil. JONES (1993) also reported parasitism of the genera Anastatus on eggs of $\boldsymbol{L}$. zonatus in Arizona (EUA).
The identification of natural enemies by the basic research may become an important alternative in the control of this pest. The groups of parasitoids that occur on maize could be selected for future studies aiming their use as agents of biological control of maize insect pests (HANSON \& GAULD, 1995).

These results contribute to the knowledge of the parasitoids occurring in the State of Goias. This is the first report of the occurrence of Anastatus sp. parasitizing immature stages of $\boldsymbol{L}$. zonatus in Brazil.

\section{ACKNOWLEDGMENTS}

I would like to thank Dr. Marcelo Teixeira Tavares, from the Universidade do Espírito Santo (Espirito Santo University), State of Espírito Santo, identified the parasitoid specie.

\section{REFERENCES}

GRISSELL, G.A.; SCHAUFF, M.E. A handebook of the families of Nearctic Chalcidoidea (Hymenoptera). Washington: Entomological Society of Washington, 1990. $86 \mathrm{p}$

HANSON, P.E.; GAULD, I.D. The Hymenoptera of Costa Rica. Oxford: University, 1995. 893p.

JONES, W.A. New host and habitat associations for some Arizona Pentatomoidea and Coreidae. S.1. : Soutwestest Entomology, 1993. 29p.

PERIOTO, N.W.; TAVARES, M.T. A Chalcidoidea. In: BRANDÃO, C.R.F.; CANCELLO, E.M. Invertebrados terrestres. Volume V. Biodiversidade do Estado de São Paulo. Síntese do conhecimento ao final do século XX. São Paulo: FAPESP, 1999. Cap.17, p.153-168.

TORRES, J.B. et al. Mortatlidae de Podisus nigrispinus (Dallas) por parasitóides de ovos em áreas de eucalipto. Anais da Sociedade Entomológica do Brasil, Londrina, v.25, n.3, p.463-472, 1996.

ZUCCHI, R.A.; NETO, S.S.; NAKANO, O. Guia de identificação de pragas agrícolas. Piracicaba : FEALQ, 1993. $139 \mathrm{p}$. 